\title{
EKSISTENSI BADAN PEMBINAAN IDEOLOGI PANCASILA (BPIP) DALAM SISTEM KETATANEGARAAN REPUBLIK INDONESIA
}

\author{
Burhanuddin \\ Fakultas Hukum Universitas Gunung Rinjani \\ e-Mail : burhanuddin2019915@gmail.com
}

\section{Info Artikel}

Sejarah Artikel :

Diterima Mei 2020

Disetujui Agustus 2020

Publikasi November 2020

\section{Keyword:}

Existence, Pancasila, State Administration System

\begin{abstract}
Alustract
Research to determine the position of the Pancasila Ideology Development Agency in the state administration system of the Republic of Indonesia. This agency was formed as a concrete effort by the government to carry out its function as state administrator in responding to the developing political situation in society, related to the emergence of several political currents and identity politics which are closely related to the role of Pancasila as the state ideology. Previously the President had issued Presidential Decree Number 54 of 2017 concerning UKP-PIP which was considered to make it difficult for the agency to coordinate with ministries and state agencies, because the UKP-PIP's authority was still at the level of the Ministry's Director General. This research uses normative legal research with statutory and conceptual approaches. The analysis technique used is qualitative analysis by collecting legal material and then editing it first to be used as material for analysis that is qualitative in nature.
\end{abstract}

\section{Ahstrak}

Penelitian untuk mengetahui kedudukan BPIP dalam sistem ketatanegara RI. Badan ini dibentuk sebagai upaya konkret pemerintah untuk menjalankan fungsinya sebagai penyelenggara negara dalam merespon situasi politik yang berkembang di masyarakat, terkait dengan munculnya beberapa aliran politik dan politik identitas yang berhubungan erat dengan peranan Pancasila sebagai ideologi negara. Sebelumnya Presiden telah menerbitkan Perpres Nomor 54 Tahun 2017 tentang UKP-PIP yang dinilai menyulitkan lembaga tersebut berkoordinasi dengan kementerian maupun lembaga negara, karena kewenangan UKP-PIP saat itu masih setingkat Direktur Jenderal Kementerian. Penelitian ini menggunakan jenis penelitian hukum normatif dengan pendekatan perundangundangan dan konseptual. Teknik analisis yang dipergunakan adalah analisis kualitatif dengan mengumpulkan bahan hukum kemudian diadakan pengeditan terlebih dahulu untuk selanjutnya dimanfaatkan sebagai bahan analisis yang sifatnya kualitatif. 


\section{A. PENDAHULUAN}

Implementasi prinsip Negara hukum mensyaratkan penyelenggaraan pemerintahan dalam bingkai Negara Kesatuan Republik Indonesia harus bersandar pada peraturan perundang-undangan. Hal ini sejalan dengan ketentuan Pasal 1 ayat (1) Undang-Undang Dasar Negara Republik Indonesia Tahun 1945 (selanjunya disebut UUD Tahun 1945) yang dinyatakan bahwa Negara Indonesia ialah Negara Kesatuan, yang berbetuk Republik. Mengacu pada ketentuan pasal 1 ayat (3) UUD NRI Tahun 1945 dinyatakan bahwa Negara Indonesia adalah Negara hukum ${ }^{1}$. Masyarakat yang semakin berkembang ternyata menghendaki negara memiliki struktur organisasi yang lebih responsif terhadap tuntutan mereka. Terwujudnya efektivitas dan efisiensi baik dalam pelaksanaan pelayanan publik maupun dalam pencapaian tujuan penyelenggaraan pemerintahan juga menjadi harapan masyarakat yang ditumpukan kepada negara.

Perkembangan tersebut memberikan pengaruh terhadap struktur organisasi negara, termasuk bentuk serta fungsi lembaga-lembaga negara. Sebagai jawaban atas tuntutan perkembangan tersebut, berdirilah lembaga-lembaga negara baru yang dapat berupa dewan (council), komisi (commission), komite (committee), badan (board), atau otorita (authority). ${ }^{2}$

Sebagai negara hukum, tanggung jawab pemerintah meskipun secara teoritis memiliki kesamaan di berbagai negara, tetapi dalam penerapannya berbeda-beda dari satu negara ke negara lainnya, hal ini dapat dilihat dari pengalaman historis dan kenyataan objektif dari masing-masing negara. Bahkan di dalam satu negarapun tentang doktrin pertanggung jawaban pemerintah ini bisa berubah-ubah yang umumnya mengikuti perubahan atau perkembangan politik di negara yang bersangkutan.

${ }^{1}$ Mahkamah Konstitusi, Undang-Undang Dasar Negara Republik Indonesia Tahun 1945, Kepaniteraan dan Sekretariat Jenderal Mahkamah Konstitusi, Cetakan Ketujuh, Januari 2017, Hal. 86

2 Jimly Asshiddiqie, 2006, Perkembangan dan Konsolidasi Lembaga Negara Pasca Reformasi, Sekretaris Jenderal dan Kepaniteraan Mahkamah Konstitusi RI, Jakarta, Hal. vi-viii.
Dari prinsip negara hukum dan pertanggung jawaban pemerintah dalam upaya penegakan hukum ini tentu sangat kental dipengaruhi oleh situasi politik negara pada masa itu. Situasi politik dapat mendorong penyelenggara negara untuk mengikuti idealisme atau sekedar bermain pragmatis mempertahankan status quo. Menentukan pilihan untuk menjadi idealis tanpa mengabaikan hal-hal yang bersifat detail dan mendesak atau memfokuskan tindakan pada jangka pendek tetapi tetap memegang teguh prinsip dan tujuan jangka panjang terkadang menjadi hal yang sulit bahkan cenderung bertentangan.

Semangat Presiden Joko Widodo untuk memerangi kegiatan yang bertentangan dengan nilai-nilai Pancasila. Harapannya, lewat keberadaan Unit Kerja Presiden Pembinaan Ideologi Pancasila (UKP-PIP), ideologi Pancasila semakin diperkuat pada masyarakat Indonesia, baik melalui pendidikan maupun kegiatan sosial, agar ke depan Pancasila benar-benar menjadi ideologi bangsa.

Akan tetapi keterbatasan kewenangan Unit Kerja Presiden Pembinaan Ideologi Pancasila (UKP-PIP) yang diatur Perpres Nomor 54 Tahun 2017 tentang UKP-PIP dinilai menyulitkan lembaga tersebut berkoordinasi dengan kementerian maupun lembaga negara. Kewenangan UKP-PIP saat itu masih setingkat direktur jenderal kementerian dan lembaga negara. Apabila kedudukan kepala UKP-PIP masih setingkat Dirjen, kinerja lembaga ini bisa terbentur ego sektoral kementerian/lembaga negara. Presiden Joko Widodo akhirnya menyetujui peningkatan kewenangan Unit Kerja Presiden Pembinaan Ideologi Pancasilan (UKP-PIP) menjadi setingkat kementerian. Menurut Kepala UKP-PIP Yudi Latif, aspek formal tengah disiapkan oleh Kementerian Pemberdayaan Aparatur Negara dan Reformasi Birokrasi (Menpan-RB), Kementerian Sekretariat Negara, Kementerian Hukum dan HAM, serta Kementerian Riset, Teknologi dan Perguruan Tinggi. $^{3}$

\footnotetext{
3 Rudy Poycarpus, UKP PIP Bakal Setingkat Kementerian, http://mediaindonesia. com/read/detail/136983-ukp-pip-bakalsetingkatkementerian, (10-3-2020)
} 
Pembentukan Badan Pembinaan Ideologi Pancasila (BPIP) oleh pemerintah pada 28 Februari 2018 merupakan upaya konkret pemerintah untuk menjalankan fungsinya sebagai penyelenggara negara dalam merespon situasi politik yang berkembang di masyarakat. Di tengah sistem demokrasi yang memunculkan pro dan kontra terkait banyaknya faham-faham yang berkembang biak belakangan ini. Bahkan, perkembangan faham yang cenderung memunculkan perpecahan di kalangan masyarakat yang dikhawatirkan dapat menggerus pemahaman dan pengamalan pancasila sebagai ideologi, pandangan hidup dan seharusnya menjadi alat pemersatu bangsa.

Dari opini dan narasi yang berkembang, Pembentukan Badan Pembinaan Ideologi Pancasila (BPIP) ini sangat kental nuansa politiknya. Dimana, keputusan dengan dikeluarkannya Peraturan Presiden (Perpres) Nomor 7 Tahun 2018, menandakan upaya serius pemerintah dalam membendung gelagat politik dari golongan-golongan yang mulai mengangkat politik identitas sebagai amunisi dalam meraih simpati dan dukungan dari masyarakat luas. Betapa tidak, situasi ini cukup memperihatinkan ketika isu SARA menjadi komoditas yang sangat laku di masyarakat dan terkesan mulai dianggap lumrah serta menjadi pijakan dari pandangan politik, khususnya masyarakat awam yang masih butuh pendidikan politik yang intensif sesuai dengan ideologi Pancasila sebagai entitas bangsa.

Untuk itulah, eksistensi dari Badan Pembinaan Ideologi Pancasila (BPIP) ini perlu mendapatkan perhatian kita semua, apalagi bagi para pengamat, akademisi maupun praktisi. Dalam rangka mengikuti terus implementasi dan efektifitas perjalanan dan capaian yang sudah ditorehkan dalam kehidupan bermasyarakat, khususnya bagi sistem ketatanegaraan Republik Indonesia. Apakah dengan adanya Badan Pembinaan Ideologi Pancasila (BPIP) ini dapat memberikan kekuatan yang baru dan memperkokoh, atau sebaliknya malah memunculkan permasalahan-permasalahan baru bagi sistem ketatanegaraan Republik Indonesia.

Adapun isu hukum dalam penelitian ini adalah sebagai berikut. Pertama, Bagaimanakah eksistensi Badan Pembinaan
Ideologi Pancasila (BPIP) dalam sistem ketatanegaraan Republik Indonesia?; Kedua, Bagaimanakah implementasi kewenangan Badan Pembinaan Ideologi Pancasila (BPIP) dalam sistem ketatanegaraan Republik Indonesia ?.

\section{B. METODE PENELITIAN}

Penelitian ini termasuk jenis hukum normatif, yaitu penelitian yang dilakukan terhadap asas-asas hukum, kaedah-kaedah hukum dalam arti nilai (norm), peraturan hukum kongkrit dan sistem hukum ${ }^{4}$. Pendekatan masalah yang digunakan adalah pendekatan perundang-undangan (Statute Approach), dilakukan dengan menelaah regulasi dan pendekatan Konseptual (Conseptual Approach) dengan mengkaji masalah penelitian ini dengan menganalisis konsep-konsep hukum serta mengkaji pandangan/konsep para ahli.

Pengumpulan bahan hukum yang digunakan dalam penelitian ini adalah dengan menggunakan alat (instrument) berupa studi kepustakaan (library research). Melalui studi kepustakaan dilakukan inventarisasi terhadap bahan-bahan hukum baik berupa peraturan perundang-undangan maupun bahan kepustakaan lainnya yang ada relevansinya dengan penelitian.

Seluruh bahan hukum yang diperoleh dari penelitian kepustakaan selanjutnya akan di analisis secara deskriptif-kualitatif. Kemudian untuk menganalisis bahan hukum yang dilakukan dengan analisis normatif kualitatif, dan diharapkan dapat menghasilkan bahan hukum deskriptif kualitatif. Bahan hukum yang diperoleh kemudian ditafsirkan pada peraturan perundang-undangan dan doktrin-doktrin hukum yang berhubungan dengan masalah yang diteliti.

\section{PEMBahasan}

\section{Sejarah Lahirnya Pancasila}

Secara umum, Pancasila dapat kita kenal dan fahami sebagai ideologi negara atau pedoman hidup bernegara di Republik Indonesia. Pancasila lahir dari pemikiran para tokoh bangsa yang digali dari nilai-nilai luhur

${ }^{4}$ Sudikmo Mertokusomo, Penemuan Hukum, Liberty, Yogyakarta, 2004, Hal. 8. 
yang sudah lama terpendam dan hidup dalam kehidupan masyarakat sejak masa lampau. Sebuah usaha yang keras telah dilakukan untuk mengkristalkannya sampai pada kesepakatan bersama dari para tokoh bangsa dan diterima oleh masyarakat di seluruh Negara Kesatuan Republik Indonesia.

Proses sejarah konseptualisasi Pancasila melintasi rangkaian perjalanan panjang, setidaknya dimulai sejak awal 1900-an dalam bentuk rintisan-rintisan gagasan untuk mencari sintesis antar ideologi dan gerakan seiring dengan proses penemuan Indonesia sebagai kode kebangsaan bersama (civic nationalism). Proses ini ditandai oleh kemunculan berbagai organisasi pergerakan kebangkitan (Boedi Oetomo, SI, Muhammadiyah, NU, Perhimpunan Indonesia, Jamiatul Khair dan lain-lain), partai politik (Indisch Partij, PNI, Partai-Partai Sosialis, PSII dan lain-lain), dan sumpah pemuda. Perumusan konseptualisasi pancasila dimulai pada masa persidangan pertama Badan Penyelidik Usaha-Usaha Persiapan Kemerdekaan Indonesia (BPUPKI) tanggal 29 Mei - 1 Juni $1945^{5}$.

Dalam sumber yang lain dijelaskan bahwa negara Republik Indonesia ketika Badan Penyelidik Usaha-Usaha Persiapan Kemerdekaan Indonesia (BPUPKI) mengadakan sidang pertama tanggal 1 Juni 1945. Saat itu sidang dipimpin oleh Ir. Soekarno sebagai anggota. Dalam pidatonya beliau menyarankan kepada peserta sidang bahwa nama falsafah negara Indonesia yang akan berdiri kelak diberi nama "Pantjasila". Istilah ini dipetik dari buku "Sutasoma" karangan Mpu Tantular. Menurut sejarah, jauh sebelum penjajahan, dan jauh sebelum berdirinya Negara Kesatuan Republik Indonesia, arti makna istilah Pancasila sudah dipedomani rakyat Indonesia di seluruh nusantara dalam kehidupan sehari-hari sebagai tuntutan perilaku. Seperti halnya istilah "MOLIMO" sudah dipedomani oleh masyarakat sebagai pedoman perilaku seharihari, artinya lima larangan yang tidak boleh dilakukan (dilarang membunuh, mencuri, mengisap ganja, berjudi dan berzina).

\footnotetext{
5 Pimpinan MPR dan Badan Sosialisasi MPR RI Periode 2014 - 2019, Materi Sosialisasi Empat Pilar MPR RI, Cet. Ke7, Sekretariat Jenderal MPR RI, 2017, Hal. 27
}

Demikian juga halnya diberbagai daerah di seluruh penjuru nusantara ${ }^{6}$.

Lahirnya Pancasila mengalami perjalanan panjang dan berfase, dalam upaya memperoleh suatu kesepakatan diantara pada pendiri bangsa. Secara historis, ada tiga rumusan dasar negara yang diberi nama Pancasila, yaitu rumusan konsep Ir. Soekarno yang disampaikan pada pidato tanggal 1 Juni 1945 dalam sidang BPUPKI, rumusan oleh panitia sembilan dalam Piagam Jakarta tanggal 22 juni 1945 dan rumusan pada pembukaan Undang-Undang Dasar 1945 yang disahkan oleh PPKI tanggal 18 Agustus $1945^{7}$.

\section{Sistem Ketatanegaraan Republik Indonesia}

Konsep negara rule of law merupakan konsep negara yang dianggap paling ideal saat ini, meskipun konsep tersebut dijalankan dengan persepsi yang berbeda-beda. Terhadap istilah rule of law ini dalam bahasa Indonesia sering juga diterjemahkan sebagai "supremasi hukum" (supremacy of law) atau "pemerintahan berdasarkan atas hukum." Di samping itu istilah "negara hukum" (government by law) atau rechstaat, juga merupakan istilah yang sering digunakan untuk itu ${ }^{8}$.

Istilah negara hukum merupakan istilah baru jika dibandingkan dengan istilah demokrasi, konstitusi maupun kedaulatan rakyat. Para ahli telah memberikan pengertian terhadap negara hukum. R. Soepomo misalnya memberikan pengertian terhadap negara hukum sebagai negara yang tunduk pada hukum, peraturan-peraturan hukum berlaku pula bagi segala badan dan alat-alat perlengkapan negara. Negara hukum juga akan menjamin tertib hukum dalam masyarakat yang artinya memberikan perlindungan hukum, antara hukum dan kekuasaan ada hubungan timbal balik ${ }^{9}$. Arief Sidharta menyatakan negara hukum sebagai

\footnotetext{
6 , Lintje Anna Marpaung, Hukum Tata Negara Indonesia, CV. Andi Offset, Yogyakarta, 2018, Hal. 20

7 Op. Cit. Pimpinan MPR dan Badan Sosialisasi MPR RI Periode 2014 - 2019, Hal. 40-41

8 Munir Fuady, Teori Negara Hukum Modern (Rechtstaat), PT. Refika Aditama, Bandung, 2009, Hal. 1

9 Sirajuddin, Winardi, Dasar-Dasar Hukum Tata Negara Indonesia, Setara Press (Kelompok Intrans Publishing), Malang, 2016, Hal. 23
} 
negara yang penyelenggaraan

pemerintahannya dijalankan berdasarkan dan bersaranakan hukum yang berakar dalam seperangkat titik tolak normatif, berupa azasazas yang menjadi pedoman dan kriteria penilaian pemerintahan dan perilaku pejabat pemerintahan ${ }^{10}$.

Teori negara hukum merupakan gagasan yang muncul untuk menentang konsep absolutisme yang telah melahirkan negara kekuasaan. Untuk zamannya, negara hukum tersebut dapat disebut revolusioner, karena mengakhiri bentuk negara sebelumnya yang bersifat otoriter. ${ }^{11}$

Karena itu, yang dimaksud dengan negara hukum adalah suatu sistem ketatanegaraan yang diatur berdasarkan hukum yang berlaku yang berkeadilan yang tersusun dalam suatu konstitusi, dimana semua orang dalam negara tersebut, baik yang diperintah maupun yang memerintah harus tunduk hukum yang sama, sehingga setiap orang yang sama diperlakukan berbeda dengan dasar pembedaan yang rasional, tanpa memandang perbedaan warna kulit, ras, gender, agama, daerah dan kepercayaan dan kewenangan pemerintah dibatasi berdasarkan suatu prinsip distribusi kekuasaan, sehingga pemerintah tidak bertidak sewenang-wenang dan tidak melanggar hak-hak rakyat, karenanya kepada rakyat diberikan peran sesuai kemampuan dan peranannya sangat demokratis. ${ }^{12}$

Dalam konteks negara hukum Indonesia, Philipus M. Hadjon menyatakan bahwa adanya pengakuan terhadap harkat dan martabat manusia dalam negara hukum Indonesia, secara intrinsik melekat pada Pancasila dan bersumber pada Pancasila. Bertitik tolak dari falsafah Negara Pancasila tersebut kemudian Hadjon merumuskan elemen atau unsur-unsur negara hukum Pancasila sebagai berikut: a) keserasian hubungan antara pemerintah dan rakyat berdasarkan azas kerukunan; b) hubungan fungsional yang proporsional antara kekuasaan negara; c) prinsip penyelesaian sengketa secara musyawarah dan peradilan

\footnotetext{
${ }^{10} \mathrm{lbid}, \mathrm{Hal} .23$

11 Ibid, Hal. 24

${ }^{12}$ Log. Cit, Munir Fuady, Hal. 3
}

merupakan sarana terakhir; d) keseimbangan antara hak dan kewajiban. ${ }^{13}$

Jimly Asshiddiqie menyebutkan bahwa paling tidak ada 11 prinsip pokok yang terkandung dalam negara hukum yang demokratis, yakni: a) adanya jaminan persamaan dan kesetaraan dalam kehidupan bersama; b) pengakuan dan penghormatan terhadap perbedaan atau pluralitas; c) adanya aturan yang mengikat dan dijadikan sumber rujukan bersama; d) adanya mekanisme penyelesaian sengketa berdasarkan mekanisme aturan yang ditaati bersama itu; e) pengakuan dan penghormatan terhadap HAM; f) pembatasan kekuasaan melalui mekanisme pemisahan dan pembagian kekuasaan disertai mekaniseme penyelesaian sengketa ketatanegaraan antar lembaga negara baik secara vertikal maupun horizontal; g) adanya peradilan yang bersifat independen dan tidak memihak dengan kewibawaan putusan tertinggi atas dasar keadilan dan kebenaran; h) dibentuknya lembaga peradilan yang khusus untuk menjamin keadilan bagi warga negara yang dirugikan akibat putusan atau kebijakan pemerintahan (pejabat administrasi negara); i) adanya mekanisme "judicial review" oleh lembaga peradilan terhadap norma-norma ketentuan legislatif baik yang ditetapkan oleh lembaga legislatif maupun eksekutif; j) dibuatnya konstitusi dan peraturan perundang-undangan yang mengatur jaminan-jaminan pelaksanaan prinsip-prinsip tersebut di atas; disertai k) pengakuan terhadap azas legalitas atau "due process of laW' dalam keseluruhan sistem penyelenggaraan negara. ${ }^{14}$

\section{Situasi yang Melatar Belakangi Berdirinya BPIP}

Setidaknya ada beberapa hal yang melatar belakangi dibentuknya Badan Pembinaan Ideologi Pancasila (BPIP) dalam sistem ketatanegaraan Republik Indonesia. Di mana latar belakang ini dapat dibagi menjadi 2 faktor, yaitu faktor internal dan faktor eksternal. Faktor internal akan sangat berhubungan erat dengan sistem ketatanegaraan Republik Indonesia, karena mengingat Badan Pembinaan Ideologi

\footnotetext{
${ }^{13}$ Op. Cit. Sirajuddin, Winardi, Hal. 30

14 Jimly Asshiddiqie, Hukum Tata Negara dan Pilar-Pilar Demokrasi, Jakarta, Konpress, 2005, Hal. 299-300
} 
Pancasila (BPIP) dibentuk sebagai upaya untuk menyempurnakan atau merevisi badan atau unit yang telah dibentuk sebelumnya, yaitu Unit Kerja Presiden Pembinaan Ideologi Pancasila (UKP-PIP).

UKP-PIP sebagai unit kerja presiden yang dibentuk pada tahun 2017 yang lalu hanya berjalan hampir setahun dan terbukti bekerja tidak efektif. Hal ini diakibatkan oleh kewenangan UKP-PIP yang masih sangat terbatas, cenderung menyulitkannya untuk bekerja dan berkoordinasi dengan lembagalembaga lainnya, baik itu lembaga setingkat kementerian. Kesulitan ini berpengaruh pula dalam mengimplementasikan apa yang menjadi fungsi, tugas dan wewenang yang harus dijalankannya.

Jika kita merujuk pada UKP-PIP yang diatur dalam Perpres Nomor 54 Tahun 2017, dapat terlihat ada beberapa fungsi dan tugas yang mendapatkan perubahan dan penambahan setelah badan atau unit ini diganti dengan Badan Pembinaan Ideologi Pancasila (BPIP). Sebelumnya, UKP-PIP memiliki tugas dan fungsi sesuai dengan pasal 3 Perpres Nomor 54 Tahun 2017 yang menyebutkan bahwa UKP-PIP mempunyai tugas membantu presiden dalam merumuskan arah kebijakan umum pembinaan ideologi Pancasila dan melaksanakan koordinasi, sinkronisasi, dan pengendalian pembinaan ideologi pancasila secara menyeluruh dan berkelanjutan ${ }^{15}$.

Setelah dibentuk Badan Pembinaan Ideologi Pancasila (BPIP), tugas tersebut mengalami revisi dan penambahan sesuai yang tertuang dalam pasal 3 Perpres Nomor 7 Tahun 2018 yaitu : BPIP mempunyai tugas membantu Presiden dalam merumuskan arah kebijakan pembinaan ideologi Pancasila, melaksanakan koordinasi, sinkronisasi, dan pengendalian pembinaan ideologi Pancasila secara menyeluruh dan berkelanjutan, dan melaksanakan penyusunan standardisasi pendidikan dan pelatihan, menyelenggarakan pendidikan dan pelatihan, serta memberikan rekomendasi berdasarkan hasil kajian terhadap kebijakan atau regulasi yang bertentangan dengan Pancasila kepada lembaga tinggi negara, kementerian/

15 Republik Indonesisa, Peraturan Presiden Nomor 54 Tahun 2017 Tentang Unit Kerja Presiden Pembinaan Ideologi Pancasila lembaga, pemerintahan daerah, organisasi sosial politik, dan komponen masyarakat lainnya ${ }^{16}$.

Tugas yang ditekankan kepada BPIP dalam landasan hukum berupa Perpres di atas menyangkut bukan hanya membantu presiden dalam merumuskan kebijakan, dengan koordinasi, sinkronisasi dan pengendalian pembinaan ideologi Pancasila yang menyeluruh dan berkelanjutan. Melainkan lebih dari itu, yaitu BPIP secara hukum memiliki tugas mewujudkan hal tersebut dengan menyelenggarakan pendidikan dan pelatihan, serta mampu memberikan rekomendasi berdasarkan hasil kajian terhadap kebijakan atau regulasi yang bertentangan dengan Pancasila, baik itu kepada lembaga tinggi negara kementerian/ lembaga, pemerintahan daerah, organisasi sosial politik, dan komponen masyarakat lainnya.

Apabila merujuk pada UUD 1945 setelah amandemen, Lembaga Tinggi Negara yang dimaksud terdiri dari : Majelis Permusyawaratan Rakyat (MPR), Dewan Perwakilan Rakyat (DPR), Dewan Perwakilan Daerah (DPD), Lembaga Kepresidenan (Presiden dan Wakil Presiden), Mahkamah Agung (MA), Mahkamah Konstitusi (MK), Badan Pemeriksaan Keuangan (BPK) dan Komisi Yudisial (KY).

Berdasarkan ketentuan Perpres Nomor 7 Tahun 2018, tentang tugas penting yang harus diemban BPIP berupa pemberian rekomendasi kepada lembaga tinggi negara, kementerian/lembaga, pemerintahan daerah, organisasi sosial politik dan komponen masyarakat lainnya tersebut menunjukkan pentingnya lembaga/badan sekelas BPIP untuk melakukan kajian-kajian yang mendalam, bahkan kajian BPIP akan menjadi suatu otoritas atau acuan penting bagi jalannya suatu kebijakan atau regulasi yang sesuai dengan ideologi Pancasila.

Fungsi Badan Pembinaan Ideologi Pancasila (BPIP) sendiri setelah merevisi fungsi dari UKP-PIP. Dimana, terdapat perbaikan dan penambahan berupa sebelas (11) fungsi penting, sesuai yang tertera dalam pasal 3 Perpres Nomor 7 Tahun 2018 sebagai berikut:

16 Republik Indonesisa, Peraturan Presiden Nomor 7 Tahun 2018 tentang Badan Pembinaan Ideologi Pancasila 


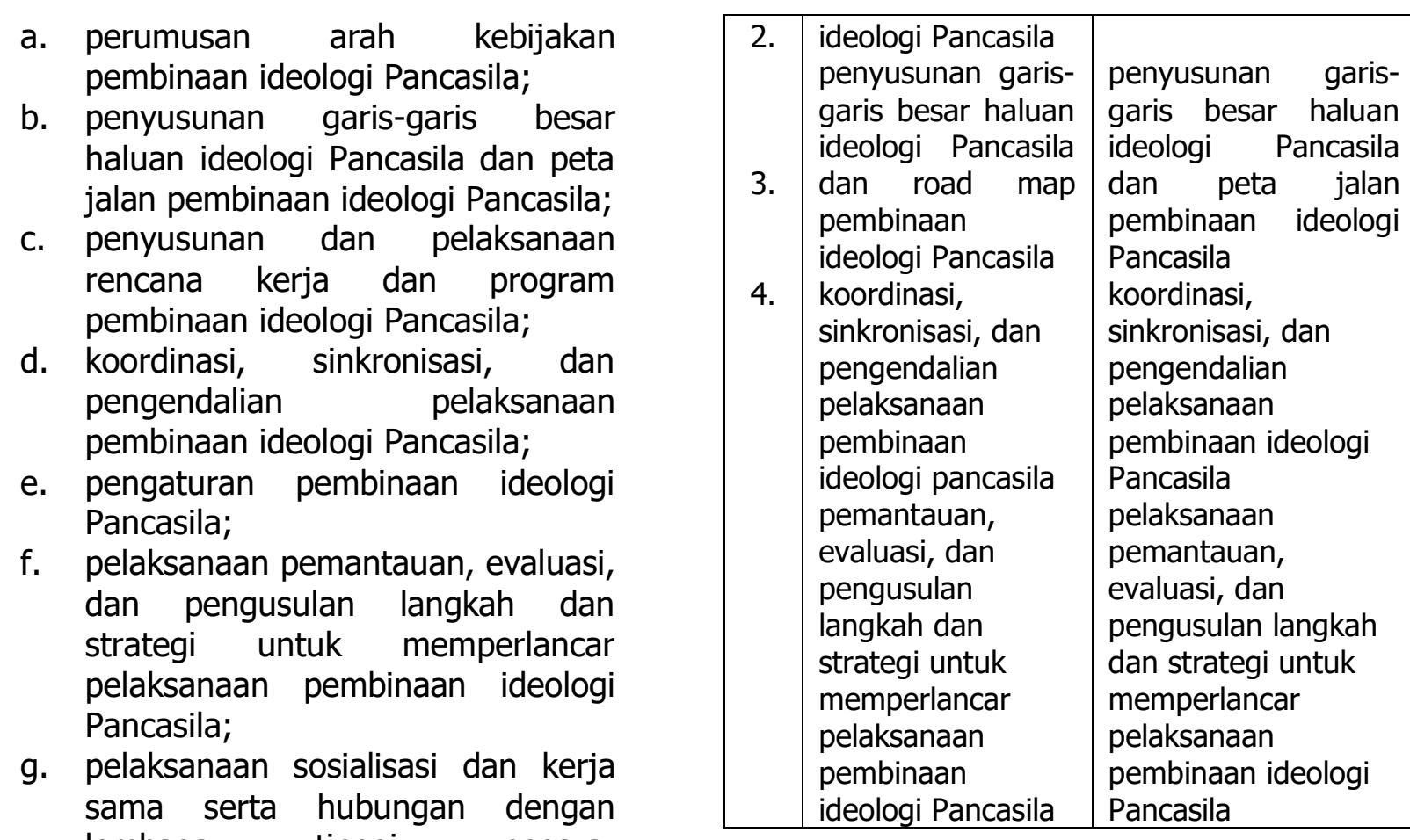
lembaga tinggi negara, kementerian/lembaga, pemerintahan daerah, organisasi sosial politik, dan komponen masyarakat lainnya dalam pelaksanaan pembinaan ideologi Pancasila;

h. pengkajian materi dan metodologi pembelajaran Pancasila;

i. advokasi penerapan pembinaan ideologi Pancasila dalam pembentukan dan pelaksanaan regulasi;

j. penyusunan standardisasi pendidikan dan pelatihan Pancasila serta menyelenggarakan pendidikan dan pelatihan; dan

k. perumusan dan penyampaian rekomendasi kebijakan atau regulasi yang bertentangan dengan Pancasila ${ }^{17}$.

Sebagai bahan kajian, ada beberapa poin fungsi yang tetap atau tidak mengalami perubahan antara fungsi UKP-PIP dengan BPIP, yang hanya berbeda dari segi bahasa saja sesuai dengan Tabel 3.1 berikut ini.

Tabel 3.1 Persamaan Fungsi UKP-PIP dan BPIP

\begin{tabular}{|c|l|l|}
\hline No & Fungsi UKP-PIP & \multicolumn{1}{c|}{ Fungsi BPIP } \\
\hline 1. & $\begin{array}{l}\text { perumusan arah } \\
\text { kebijakan umum } \\
\text { pembinaan }\end{array}$ & $\begin{array}{l}\text { perumusan arah } \\
\text { kebijakan pembinaan } \\
\text { ideologi Pancasila }\end{array}$ \\
\hline
\end{tabular}

17 Ibid, Hal. 4
Dari Tabel 3.1 dapat diperoleh gambaran bahwa dibentuknya UKP-PIP dan BPIP memiliki tujuan yang serius dalam memberikan rumusan, petunjuk serta arahan yang jelas dan tertuang dalam tugas yang harus diimplementasikan dalam pembinaan ideologi Pancasila bagi Negara Republik Indonesia. Pengimplementasian ini akan dapat terwujud dan berjalan dengan lancar manakala dapat tertuang secara jelas dalam hukum atau peraturan yang berlaku, sehingga pembinaan ideologi ini tidak tumpang tindih dan dapat dipertanggung jawabkan secara hukum. Terutama dalam peran sebuah ideologi Negara dalam sistem ketatanegaraan, dan dapat mensasar seluruh lapisan masyarakat tanpa terkecuali.

Artinya, fungsi mendasar yang dimiliki oleh kedua lembaga ini terletak pada perumusan, penyusunan garis-garis besar, koordinasi, sinkronisasi, pengendalian pelaksanaan, pemantauan dan evaluasi serta pengusulan langkah dan strategi untuk memperlancar pelaksanaan ideologi Pancasila. Sehingga, fungsi badan ini selain sebagai perencana, pelaksana dan pengevaluasi bagi kerja internal tapi juga berfungsi pula untuk berbagai macam kegiatan yang berhubungan dengan penanaman ideologi Pancasila yang diselenggarakan oleh seluruh komponen negara dan masyarakat. 
Perumusan arah kebijakan dalam pembinaan ideologi Pancasila menjadi hal yang pokok dalam sistem ketatanegaraan Republik Indonesia. Mengingat, sistem ketatanegaraan ini sudah berlangsung puluhan tahun semenjak proklamasi dicetuskan, lebih tepatnya sudah berlangsung 75 tahun berjalan. Tentu, selama perjalanannya membutuhkan penyesuaian atau relevansi terhadap konteks perkembangan zaman dalam kehidupan bernegara, maupun hubungan antar negara. Namun, dalam penyesuaian dengan konteks perkembangan zaman ini, ideologi negara tetap menjadi dasar dan acuan dalam bersikap maupun dalam menerapkan sistem hukum yang berlaku. Mengatasi dilema dalam menjalankan dan mempertahankan ideologi negara dengan upaya menyesuaikan diri dan bertarung dengan perkembangan zaman merupakan hal terberat, apalagi dalam corak masyarakat Indonesia yang beraneka ragam.

Tugas penyusunan garis-garis besar ideologi negara menjadi hal yang terpenting selanjutnya dalam corak masyarakat yang beraneka ragam, yang memunculkan banyaknya aliran-aliran, identitas dan berbagai ajaran-ajaran yang bisa saja berakibat memunculkan berbagai macam kepentingan pula. Untuk itu, peran dari berbagai tokoh bangsa penting sekali dalam menyusun batasan-batasan dan capaiancapaian ideologi negara yang harus ditanamkan dan digerakkan untuk membendung bahkan mengatasi gejolak atau konflik yang cenderung terjadi dalam corak masyarakat yang beraneka ragam ini. Meskipun demikian, corak masyarakat Indonesia yang beraneka ragam ini memiliki keuntungan yang besar dengan kekayaan khazanahnya serta terbukti dapat bersatu dalam negara kesatuan Republik Indonesia selama bertahun-tahun bahkan berabad lamanya.

Selain itu, arus globalisasi tata-nilai membawa dampak pluralisasi, polarisasi, dan fragmentasi ideologi dalam kehidupan kebangsaan yang makin luas cakupannya, dalam penetrasinya dan kecepatannya. Dalam menghadapi perkembangan ini, eksistensi Indonesia sebagai republik dituntut untuk berdiri kokoh di atas cita negara dan cita hukum Pancasila. Tantangan-tantangan tersebut membutuhkan peran strategis lembaga dalam melakukan pembinaan Pancasila secara terpimpin, terencana, terstruktur, sistematis dan terpadu.

Beberapa poin yang mengalami revisi dan penambahan redaksi di setiap fungsi yang dimiliki antara UKP-PIP dengan BPIP, yaitu :

Tabel 3.2 Poin Revisi dan Penambahan Redaksi Pada Fungsi antara UKP-PIP dan BPIP

\begin{tabular}{|l|l|l|}
\hline No & $\begin{array}{l}\text { Fungsi UKP- } \\
\text { PIP }\end{array}$ & \multicolumn{1}{c|}{ Fungsi BPIP } \\
\hline 1. & $\begin{array}{l}\text { pelaksanaan } \\
\text { advokasi } \\
\text { pembinaan } \\
\text { ideologi } \\
\text { 2. }\end{array}$ & $\begin{array}{l}\text { advokasi penerapan } \\
\text { pembinaan ideologi } \\
\text { Pancasila dalam } \\
\text { pembentukan dan } \\
\text { pelaksanaan regulasi } \\
\text { pelaksanaan sosialisasi } \\
\text { dan kerja sama serta } \\
\text { hubungan dengan }\end{array}$ \\
& $\begin{array}{l}\text { pelaksanaan } \\
\text { kerja sama dan } \\
\text { hubungan antar } \\
\text { lembaga dalam } \\
\text { lembaga tinggi negara, } \\
\text { pelaksanaan } \\
\text { pembinaan } \\
\text { ideologi }\end{array}$ & $\begin{array}{l}\text { kementerian/lembaga, } \\
\text { pemerintahan daerah, } \\
\text { organisasi sosial politik, } \\
\text { dan komponen } \\
\text { Pancasila }\end{array}$ \\
& $\begin{array}{l}\text { masyarakat lainnya } \\
\text { dalam pelaksanaan } \\
\text { pembinaan ideologi } \\
\text { Pancasila }\end{array}$ \\
\hline
\end{tabular}

Dalam Tabel 3.2 terlihat bahwa fungsi UKP-PIP memiliki redaksi yang singkat dalam penjabarannya tentang pelaksanaan advokasi, pelaksanaan kerjasama dan hubungan antar lembaga dalam pembinaan ideologi Pancasila. Sedangkan, fungsi yang dimiliki BPIP menekankan dan mengerucut pada pelaksanaan advokasi dalam pembentukan dan pelaksanaan regulasi penerapan pembinaan ideologi Pancasila. Artinya, fungsi UKP-PIP sebelumnya tidak menjabarkan ruang lingkup advokasi yang disasar, yaitu terkait dengan pelaksanaan dan pembentukan regulasi dalam upaya pembinaan ideologi Pancasila. Dalam fungsi BPIP itu penting dicantumkan karena dalam setiap advokasi membutuhkan legalitas yang kuat, sehingga tidak terjadi kegamangan dalam menafsirkan tugas advokasi sekaligus ketika menjalankannya.

Fungsi yang berbeda dari penambahan redaksi antara UKP-PIP dengan BPIP juga terletak pada fungsi kerja sama dan hubungan antar lembaga dalam pelaksanaan pembinaan ideologi Pancasila. Dalam fungsi 
BPIP ditambahkan dengan kalimat pelaksanaan sosialisasi dan penjabaran yang detail tentang ruang lingkup disasarnya fungsi ini, yaitu dengan lembaga tinggi negara, kementerian/lembaga, pemerintahan daerah, organisasi sosial politik, dan komponen masyarakat lainnya.

Adapun beberapa poin tambahan pada fungsi yang tidak terdapat dalam fungsi UKPPIP, tapi terdapat pada fungsi BPIP adalah sebagai berikut :
a. pengaturan pembinaan ideologi Pancasila;
b. pengkajian materi dan metodologi pembelajaran Pancasila;
c. penyusunan standardisasi pendidikan menyelenggarakan pendidikan dan dan pelatihan Pancasila serta pelatihan; dan

d. perumusan dan penyampaian rekomendasi kebijakan atau regulasi yang bertentangan dengan Pancasila.

Pada poin pertama, terdapat pernyataan bahwa fungsi BPIP adalah untuk mengatur pembinaan ideologi Pancasila. Pernyataan ini cukup sederhana dan memiliki arti yang umum, sehingga cukup merangsang banyak interpretasi terhadapnya. Karena, jika diperhatikan makna dari pengaturan ini dapat mencakup membuat, mengontrol sampai pada mengkoordinasikan sebuah kebijakan. Artinya, pengaturan ini sudah mencakup pada perumusan, perencanaan, koordinasi, sinkronikasi, dan penyelenggaraan yang sudah dicantumkan pada poin-poin fungsi yang lainnya.

Pada poin kedua, yaitu pengkajian materi dan metodologi pembelajaran Pancasila. Menunjukkan fungsi yang lebih spesifik menyangkut pembumian ideologi Pancasila melalui aspek pendidikan. Tidak hanya sekedar menentukan garis-garis besar, melakukan sinkronisasi, dan pengendalian secara umum terhadap pembinaan ideologi Pancasila, melainkan fungsi-fungsi ini harus didetailkan materi dan metodologinya. Karena, keanekaragaman yang muncul terutama khazanah keilmuan yang ada di Indonesia, menjadikan banyak pula munculnya pandangan (perspektif) yang berbeda menyangkut filosofi dan implementasi ideologi Pancasila dalam kehidupan bernegara. Jadi penyatuan pandangan merupakan tujuan yang pokok dari fungsi BPIP dalam melakukan kajian materi dan meteri pembelajaran Pancasila tersebut.

Poin ketiga tentang penyusunan standardisasi pendidikan dan pelatihan Pancasila serta menyelenggarakan pendidikan dan pelatihan, merupakan kelanjutan dari fungsi tentang pengkajian materi dan metodologi pembelajaran Pancasila. Dimana, setelah BPIP melakukan kajian terhadap materi dan metodologi pembelajaran Pancasila, maka penting baginya untuk membuat standar ketika diimplementasikan dalam penyelenggaran pendidikan dan pelatihan, baik yang dilakukan oleh BPIP sendiri maupun pihak lain, yang memiliki wewenang dan kebutuhan dalam pembinaan ideologi Pancasila.

Poin keempat ini tidak kalah penting, yaitu perumusan dan penyampaian rekomendasi kebijakan atau regulasi yang bertentangan dengan Pancasila. Karena dalam upaya pengkajian materi dan metodologi sampai pada standarisasi pelaksanaan pendidikan dan pelatihan, BPIP akan dihadapkan pada kebijakan dan regulasi yang ada jauh sebelumnya maupun yang masih menjadi rancangan peraturan diberbagai tingkat dalam sistem ketatanegaraan Republik Indonesia. Dimana, regulasi dan kebijakaan tersebut tidak akan jauh-jauh dari kajian-kajian yang harus dilakukan BPIP sendiri. Sehingga, hasil kajian -kajian yang dilakukan dapat membuahkan hasil ketika BPIP diberikan wewenang yang cukup besar dalam memberikan rekomendasi yang membangun bagi penyelenggara negara. Dengan demikian, regulasi ataupun kebijakan yang diterapkan dapat disortir dan direvisi sehingga tidak bertentangan dengan ideologi Negara.

Maka, sistem ketatanegeraan Republik Indonesia membutuhkan lembaga khusus dalam mengawal dan memelihara eksistensi ideologi Pancasila ini dengan tugas, fungsi dan kewenangan yang jelas. Pengawalan dan pemeliharaan ini membutuhkan usaha perencanaan, perumusan, pengkontrolan, pengadaan/penyelenggaraan, koordinasi, sosialisasi, kerjasama-kerjasama, evaluasi hingga pada usaha advokasi yang terukur. Yang tentu saja, dalam mengemban amanah kelembagaan ini dibutuhkan pihak-pihak yang mumpuni, memiliki kompetensi, elektabilitas 
serta pengaruh yang besar dalam segala aspek kehidupan bernegara. Dengan disahkannya Perpres No.7 Tahun 2018 menjadi dasar hukum yang kuat untuk memenuhi dan mencapai tujuan yang diamanatkan dalam Keputusan Presiden No. 24 Tahun 2016 bahwa Pancasila sebagai dasar dan ideologi Negara Republik Indonesia harus diketahui asal usulnya oleh bangsa Indonesia dari waktu ke waktu dan dari generasi ke generasi, sehingga kelestarian dan kelanggengan Pancasila senantiasa diamalkan dalam kehidupan bermasyarakat, berbangsa, dan bernegara.

\section{Implementasi Kewenangan BPIP dalam Sistem Ketatanegaraan RI}

Mengingat tujuan dari dibentuknya Badan pembinaan Ideologi Pancasila yang merujuk pada Keputusan Presiden Nomor 24 Tahun 2016 tentang Hari Lahir Pancasila. Dimana, Pancasila sebagai dasar dan ideologi Negara Republik Indonesia harus diketahui asal usulnya oleh bangsa Indonesia dari waktu ke waktu dan dari generasi ke generasi, sehingga kelestarian dan kelanggengan Pancasila senantiasa diamalkan dalam kehidupan bermasyarakat, berbangsa, dan bernegara. Sebagai badan yang memiliki tugas, fungsi dan wewenang yang cukup besar, maka BPIP tentu harus memiliki capaian-capaian yang bersifat jangka pendek dan jangka panjang. Sedikit tidak ada capaian yang sudah dirumuskan sejauh ini sejak BPIP didirikan.

Badan Pembinaan Ideologi Pancasila turut mendukung agenda prioritas atau Nawa Cita. Dimana, intisari dari program Nawacita pemerintah tersebut adalah :

a. Menghadirkan kembali Negara untuk melindungi segenap bangsa dan memberikan rasa aman pada seluruh warga Negara, melalui politik luar negeri bebas aktif, keamanan nasional yang terpercaya dan pembangunan pertahanan Negara Tri Matra terpadu yang dilandasi kepentingan nasional dan memperkuat jati diri sebagai Negara maritim;

b. Membuat pemerintah tidak absen dengan membangun tata kelola pemerintahan yang bersih, efektif, demokratis, dan terpercaya dengan memberikan prioritas pada upaya memulihkan kepercayaan pada institusiinstitusi demokrasi dengan melanjutkan konsolidasi demokrasi melalui reformasi sistem kepartaian, pemilu dan lembaga perwakilan;

c. Membangun Indonesia dari pinggiran dengan memperkuat daerah-daerah dan desa dalam kerangka Negara kesatuan;

d. Menolak Negara lemah dengan melakukan reformasi sistem dan penegakan hukum yang bebas korupsi, bermartabat dan terpercaya;

e. Meningkatkan kualitas hidup manusia Indonesia melalui peningkatan kualitas pendidikan dan pelatihan dengan program "Indonesia Pintar" serta peningkatan kesejahteraan masyarakat dengan program "Indonesia Kerja" dan "Indonesia Sejahtera" dengan mendorong land reform dan program kepemilikan tanah seluas 9 hektar, program rumah kampung deret atau rumah susun murah yang disubsidi serta jaminan sosial untuk rakyat pada tahun 2019;

f. Meningkatkan produktivitas rakyat dan daya saing di pasar internasional sehingga bangsa Indonesia bias maju dan bangkit bersama bangsa-bangsa Asia lainnya;

g. Mewujudkan kemandirian ekonomi dengan menggerakkan sector-sektor strategis ekonomi domestik;

h. Melakukan revoluasi karakter bangsa melalui kebijakan penataan kembali kurikulum pendidikan nasional dengan mengedepankan aspek pendidikan kewarganegaraan, yang menempatkan secara proporsional aspek pendidikan, seperti pengajaran sejarah pembentukan bangasa, nilai-nilai patriotism dan cinta tanah air, semangat bela Negara dan budi pekerti di dalam kurikulum pendidikan Indonesia;

i. Memperteguh kebhinekaan dan memperkuat restorasi sosial Indonesia melalui kebijakan memperkuat pendidikan kebhinekaan dan menciptakan ruang-ruang dialog antarwarga $^{18}$.

18 Media, Kompas Cyber, Nawa Cita", 9 Agenda Prioritas Jokowi-JK-Kompas.com. (9-5-2020) 
Badan Pembinaan Ideologi Pancasila turut mendukung agenda prioritas atau Nawa Cita, yaitu : melakukan revolusi karakter bangsa melalui kebijakan penataan kembali kurikulum pendidikan Nasional dengan mengedepankan aspek pendidikan kewarganegaraan, yang menempatkan secara proporsional aspek pendidikan seperti pengajaran sejarah pembentukan bangsa, nilai-nilai patriotisme dan cinta tanah air, semangat bela negara dan budi pekerti di dalam kurikulum pendidikan Indonesia, memperteguh kebhinekaan dan memperkuat restorasi sosial Indonesia melalui kebijakan memperkuat pendidikan kebhinekaan dan menciptakan ruang dialog antar warga ${ }^{19}$.

Aspek strategis BPIP dalam rangka mendukung cita-cita tersebut adalah melalui program teknis pembinaan ideologi Pancasila bagi masyarakat, penyelenggara negara, dan aparat penegak hukum, serta berbagai pihak untuk taat dan patuh dengan berlandaskan dan berdasarkan nilai-nilai Pancasila. Sejatinya nilai-nilai Pancasila merupakan jati diri bangsa yang terbukti sangat ampuh menjaga Negara Kesatuan Republik Indonesia.

Untuk mengkaji dan mengukur sejauh mana capaian-capaian BPIP dalam melaksanakan tugas, fungsi dan wewenangnya sesuai dengan peraturan perundang-undangan yang berlaku, maka capaian kerja tahun anggaran 2019 dapat dijadikan kajian dan ukuran. Sejauh ini, analisis capaian kinerja BPIP Tahun 2019 terbatas pada pelaksanakan program selama kurang dari 3 bulan, yaitu bulan Oktober hingga Desember 2019. Sebagai Lembaga yang baru berdiri, kinerja dalam kurun waktu tersebut tentu belum dapat diukur secara menyeluruh dalam lingkup Sistem Akuntabilitas Kinerja. Pengukuran capaian kinerja dilakukan dengan pendekatan aksi atau kegiatan yang mendukung tercapainya Sasaran Strategis (SS). Hasil pengukuran capaian indikator kinerja adalah sebagai berikut:

Tabel 3.5 Capaian Indikator Badan Pembinaan Ideologi Pancasila (BPIP) ${ }^{20}$

\begin{tabular}{|c|c|c|c|c|c|}
\hline $\begin{array}{c}\text { Sas } \\
\text { ara }\end{array}$ & $\begin{array}{c}\text { Indik } \\
\text { ator }\end{array}$ & $\begin{array}{c}\text { Targ } \\
\text { et }\end{array}$ & $\begin{array}{c}\text { Re } \\
\text { alis }\end{array}$ & $\begin{array}{c}\text { Keteranga } \\
\text { n }\end{array}$ & $\begin{array}{c}\text { Keteranga } \\
\text { n }\end{array}$ \\
\hline
\end{tabular}

19 Laporan Kinerja Badan Pembinaan Ideologi Pancasila Republik Indonesia 2019, Hal.6

20 lbid, Hal. 16

\begin{tabular}{|c|c|c|c|c|c|}
\hline $\begin{array}{c}n \\
\text { Stra } \\
\text { tegi } \\
\mathbf{s} \\
\end{array}$ & $\begin{array}{c}\text { Kinerj } \\
\text { a } \\
\text { Utam } \\
\text { a } \\
\end{array}$ & & asi & $\begin{array}{c}\text { (Penguku } \\
\text { ran } \\
\text { Target) }\end{array}$ & $\begin{array}{c}\text { (Pengukur } \\
\text { an } \\
\text { Realisasi) }\end{array}$ \\
\hline $\begin{array}{l}\text { Terj } \\
\text { adin } \\
\text { ya } \\
\text { revit } \\
\text { alisa } \\
\text { si } \\
\text { dan } \\
\text { reak } \\
\text { tuali } \\
\text { sasi } \\
\text { pem } \\
\text { aha } \\
\text { man } \\
\text { nilai- } \\
\text { nilai } \\
\text { Panc } \\
\text { asila }\end{array}$ & $\begin{array}{l}\text { Persen } \\
\text { tase } \\
\text { hasil } \\
\text { rekom } \\
\text { endasi } \\
\text { hasil } \\
\text { koordi } \\
\text { nasi, } \\
\text { sinkro } \\
\text { nisasi } \\
\text { dan } \\
\text { penge } \\
\text { ndalia } \\
\text { n } \\
\text { pembi } \\
\text { naan } \\
\text { ideolo } \\
\text { gi } \\
\text { Pancas } \\
\text { ila } \\
\text { yang } \\
\text { dimanf } \\
\text { aatkan }\end{array}$ & $80 \%$ & $\begin{array}{l}65 \\
\%\end{array}$ & $\begin{array}{l}\text { Ukuran } \\
\text { dimanfaatk } \\
\text { an adalah } \\
\text { oleh } \\
\text { presiden/de } \\
\text { wan } \\
\text { pengarah } \\
(20 \%) \text {, } \\
\text { GBHIP } \\
(20 \%) \text {, } \\
\text { peta jalan } \\
\text { PIP (20\%), } \\
\text { alat ukur } \\
\text { pengendali } \\
\text { an dan } \\
\text { evaluasi } \\
\text { kebijakan } \\
\text { PIP (20\%), } \\
\text { standarisasi } \\
\text { kurikulum } \\
\text { (20\%) }\end{array}$ & $\begin{array}{l}\text { Presidential } \\
\text { Lecture } \\
(20 \%), \\
\text { GBHIP } \\
(15 \%) \text {, alat } \\
\text { ukur } \\
\text { pengendali } \\
\text { an evaluasi } \\
\text { kebijakan } \\
\text { PIP (15\%), } \\
\text { standarisasi } \\
\text { Kurikulum } \\
(15 \%)\end{array}$ \\
\hline $\begin{array}{l}\text { Terci } \\
\text { ptan } \\
\text { ya } \\
\text { inklu } \\
\text { si } \\
\text { sosia } \\
\text { I di } \\
\text { kala } \\
\text { ngan } \\
\text { mas } \\
\text { yara } \\
\text { kat }\end{array}$ & $\begin{array}{l}\text { Persen } \\
\text { tase } \\
\text { geraka } \\
\text { n } \\
\text { inklusi } \\
\text { nilai- } \\
\text { nilai } \\
\text { Pancas } \\
\text { ila } \\
\text { bagi } \\
\text { kompo } \\
\text { nen } \\
\text { masya } \\
\text { rakat }\end{array}$ & $80 \%$ & $\begin{array}{l}60 \\
\%\end{array}$ & $\begin{array}{l}\text { Penyebaran } \\
\text { nilai-nilai } \\
\text { Pancasila } \\
\text { kepada: } 1 . \\
\text { Lembaga } \\
\text { tinggi } \\
\text { Negara; } 2 \text {. } \\
\text { Kementeria } \\
\text { n/lembaga; } \\
3 . \\
\text { Pemerintah } \\
\text { an daerah; } \\
\text { 4. } \\
\text { Organisasi } \\
\text { sosial } \\
\text { politik; } 5 . \\
\text { Komponen } \\
\text { masyarakat } \\
\text { lainnya }\end{array}$ & $\begin{array}{l}\text { penyebaran } \\
\text { nilai-nilai } \\
\text { Pancasila } \\
\text { kepada } \\
\text { pemangku } \\
\text { kepentinga } \\
\text { n melalui } \\
\text { kegiatan } \\
\text { persamuha } \\
\text { n dan } \\
\text { perkemaha } \\
\text { n, } \\
\text { sosialisasi }\end{array}$ \\
\hline $\begin{array}{l}\text { Ter } \\
\text { wuju } \\
\text { dnya } \\
\text { kead } \\
\text { ilan } \\
\text { sosia } \\
\text { I } \\
\text { mela } \\
\text { lui } \\
\text { pem } \\
\text { bang } \\
\text { una } \\
\text { n } \\
\text { berb } \\
\text { asis } \\
\text { Panc } \\
\text { asila }\end{array}$ & $\begin{array}{l}\text { Persen } \\
\text { tase } \\
\text { koordi } \\
\text { nasi } \\
\text { pengu } \\
\text { atan } \\
\text { pemen } \\
\text { uhan } \\
\text { hak } \\
\text { kelom } \\
\text { pok } \\
\text { rentan } \\
\text { yang } \\
\text { dimanf } \\
\text { aatkan }\end{array}$ & $80 \%$ & $\begin{array}{l}60 \\
\%\end{array}$ & $\begin{array}{l}\text { Program } \\
\text { kegiatan } \\
\text { advokasi } \\
\text { kepada } \\
\text { masyarakat } \\
\text { (misal: } \\
\text { kejadian } \\
\text { bela diri } \\
\text { begal, hak } \\
\text { tanah } \\
\text { ulayat, } \\
\text { kelompok } \\
\text { rentan } \\
\text { seperti: } \\
\text { perempuan } \\
\text { dan anak- } \\
\text { anak, dll }\end{array}$ & $\begin{array}{l}\text { Advokasi } \\
\text { permasalah } \\
\text { an pada } \\
\text { kelompok } \\
\text { rentan } \\
\text { seperti: } \\
\text { perempuan }\end{array}$ \\
\hline $\begin{array}{l}\text { Ter } \\
\text { wuju } \\
\text { dnya } \\
\text { pele } \\
\text { mba } \\
\text { gaan } \\
\text { Panc } \\
\text { asila } \\
\text { pada } \\
\text { setia } \\
\text { p }\end{array}$ & $\begin{array}{l}\text { Persen } \\
\text { tase } \\
\text { sinkro } \\
\text { nisasi } \\
\text { nilai- } \\
\text { nilai } \\
\text { Pancas } \\
\text { ila } \\
\text { pada } \\
\text { regula } \\
\text { si }\end{array}$ & $85 \%$ & $\begin{array}{l}84 \\
\%\end{array}$ & $\begin{array}{l}\text { Analisis } \\
\text { regulasi } \\
\text { terhadap } \\
\text { nilai-nilai } \\
\text { Pancasila } \\
(150 \\
\text { Regulasi) }\end{array}$ & $\begin{array}{l}84 \text { Undang- } \\
\text { Undang, } 42 \\
\text { peraturan } \\
\text { daerah } \\
\text { (126 } \\
\text { Regulasi) }\end{array}$ \\
\hline
\end{tabular}




\begin{tabular}{|c|c|c|c|c|c|}
\hline $\begin{array}{l}\text { pera } \\
\text { tura } \\
\text { n } \\
\text { peru } \\
\text { ndan } \\
\text { g- } \\
\text { unda } \\
\text { ngan }\end{array}$ & $\begin{array}{l}\text { yang } \\
\text { ditinda } \\
\mathrm{k} \\
\text { lanjuti }\end{array}$ & & & & \\
\hline $\begin{array}{l}\text { Tera } \\
\text { ktual } \\
\text { isasi } \\
\text { nya } \\
\text { nilai- } \\
\text { nilai } \\
\text { Panc } \\
\text { asila } \\
\text { mela } \\
\text { lui } \\
\text { ketel } \\
\text { adan } \\
\text { an } \\
\text { Panc } \\
\text { asila }\end{array}$ & $\begin{array}{l}\text { Persen } \\
\text { tase } \\
\text { apresi } \\
\text { asi } \\
\text { insan } \\
\text { aktuali } \\
\text { sasi } \\
\text { nilai } \\
\text { Pancas } \\
\text { ila }\end{array}$ & $\begin{array}{c}100 \\
\%\end{array}$ & $\begin{array}{c}100 \\
\%\end{array}$ & $\begin{array}{l}\text { Menilai } \\
\text { insan } \\
\text { teladan } \\
\text { Pancasila } \\
\text { (74 insan } \\
\text { teladan) }\end{array}$ & $\begin{array}{l}\text { Menilai } \\
\text { insan } \\
\text { teladan } \\
\text { Pancasila } \\
\text { (74 insan } \\
\text { teladan) }\end{array}$ \\
\hline
\end{tabular}

Aspek strategis BPIP dalam rangka mendukung cita-cita nawacita dari pemerintah adalah melalui program teknis pembinaan ideologi Pancasila bagi masyarakat, penyelenggara negara, dan aparat penegak hukum, serta berbagai pihak untuk taat dan patuh dengan berlandaskan dan berdasarkan nilai-nilai Pancasila. Sejatinya nilai-nilai Pancasila merupakan jati diri bangsa yang terbukti sangat ampuh menjaga Negara Kesatuan Republik Indonesia.

Ketika negara dihadapkan pada tantangan ideologi, pengalaman traumatis instrumental Pancasila di masa lalu membuat kepercayaan penyelenggara dan warga negara terhadap Pancasila merosot. Selama beberapa tahun kebelakang, Pancasila tidak lagi menjadi pelajaran wajib di sekolah, bahkan ada kegamangan di kalangan penyelenggara negara untuk mengartikulasikan Pancasila di ruang publik. Situasi demikian membuat pasokan moral bagi peserta didik hanya diisi oleh moral partikularitas keagamaan yang cenderung diisi oleh kelompok-kelompok militan, yang membuat peserta didik kurang terpapar dan terbudayakan dalam moral publik. Kalaupun ada program bina ideologi dan mental yang dilaksanakan oleh kementerian/Lembaga $(K / L)$, selama ini pada umumnya bersifat superfisial/permukaan, dan kompartementalis, tanpa adanya kejelasan arah, sistematika, struktur dan koordinasi ${ }^{21}$.

${ }^{21}$ Ibid, Hal. $6-7$
Dalam menjalankan kewenangannya, Badan Pembinaan Ideologi Pancasila (BPIP) sebagai garda terdepan dalam upaya pembinaan ideologi Pancasila tersusun dan terorganisir serta ditempati oleh pihak-pihak yang memiliki kompetensi, pengaruh besar atau kemampuan yang dapat diandalkan. Dalam Peraturan Presiden No. 7 Tahun 2018, dipaparkan tentang keorganisasian Badan Pembinaan Ideologi (BPIP) pada pasal 5 bahwa susunan organisasi BPIP terdiri atas:

a. Dewan Pengarah, yang terdiri atas:
1. Ketua; dan
2. Anggota.

b. pelaksana, yang terdiri atas:

1. Kepala;

2. Wakil Kepala;

3. Sekretariat Utama;

4. Deputi Bidang Hubungan Antar Lembaga, Sosialisasi, Komunikasi, dan Jaringan;

5. Deputi Bidang Hukum, Advokasi, dan Pengawasan Regulasi;

6. Deputi Bidang Pengkajian dan Materi;

7. Deputi Bidang Pendidikan dan Pelatihan; dan

8. Deputi Bidang Pengendalian dan Evaluasi22.

Struktur organisasi berdasarkan Peraturan Badan Pembinaan Ideologi Pancasila Nomor 1 Tahun 2018 tentang Organisasi dan Tata Kerja Badan Pembinaan Ideologi Pancasila, terdiri dari Dewan Pengarah mempunyai tugas memberikan arahan kepada pelaksana terkait arah kebijakan pembinaan ideologi Pancasila. Arahan sebagaimana dimaksud merupakan hasil pembahasan dalam rapat Dewan Pengarah yang ditetapkan oleh Ketua Dewan Pengarah. Dewan Pengarah berjumlah paling banyak sebelas (11) orang, yang terdiri atas unsur:

a. tokoh kenegaraan;

b. tokoh agama dan masyarakat; dan

c. tokoh purnawirawan Tentara Nasional Indonesia/Kepolisian Negara Republik Indonesia, pensiunan Pegawai Negeri Sipil dan akademisi ${ }^{23}$.

22 Peraturan Presiden Nomor 7 Tahun 2018 Tentang Badan Pembinaan Ideologi Pancasila, Hal. 5

${ }^{23}$ Peraturan Presiden Nomor 7 Tahun 2018 Tentang Badan Pembinaan Ideologi Pancasila, Hal. 5-6 
Rencana Strategis BPIP disusun berdasarkan analisis situasi kebangsaan dan kenegaraan menurut perspektif BPIP. Indikator keberhasilan atau kinerja, keluaran (output), hasil (outcome), dan dampak (impact) BPIP menjadi perhatian utama hadirnya lembaga ini dalam tata kelola penyelenggaraan negara di Indonesia ${ }^{24}$.

Rencana Strategis BPIP merupakan penjabaran dari Visi, Misi, Tugas, dan Fungsi BPIP sebagaimana yang diamanatkan dalam Peraturan Presiden Nomor 7 Tahun 2018 tentang Badan Pembinaan Ideologi Pancasila yang kemudian disintesakan dengan hasil analisa situasi tentang kekuatan dan kelemahan internal berdasarkan hasil evaluasi yang akurat, serta hasil analisis peluang dan ancaman yang ada dalam lingkungan strategik eksternal. Rencana strategis BPIP 2018-2023 dituangkan dalam Peraturan BPIP Nomor 5 Tahun $2018^{25}$.

Berdasarkan hal itu maka Visi BPIP adalah menjadi institusi penyemai nilai Pancasila dalam kehidupan berbangsa, dan bernegara pada dimensi keyakinan, pengetahuan, dan tindakan dengan semangat gotong royong untuk mewujudkan cita-cita nasional. Misinya adalah Membudayakan nilai Pancasila di kalangan penyelenggara negara dan warga negara Indonesia agar menjadi pendirian hidup dan perilaku hidup berbangsa dan bernegara ${ }^{26}$.

Dalam upaya mewujudkan visi dan misi organisasi berdasarkan Peraturan BPIP Nomor 5 Tahun 2018, BPIP memiliki tujuan sebagai berikut :

a. Revitalisasi dan reaktualisasi pemahaman nilai-nilai Pancasila

b. Konsepsi dan acuan pembudayaan berupa keyakinan, pengetahuan dan tindakan atas nilai-nilai Pancasila

c. Pembinaan ideologi Pancasila secara terkoordinasi, sinkron dan terkendali

d. Keterlibatan berbagai kepentingan dalam proses pembudayaan

e. Menyemai nilai-nilai Pancasila dalam penyelenggaraan negara dan kehidupan

\footnotetext{
${ }^{24}$ Laporan Kinerja Badan Pembinaan Ideologi Pancasila Republik Indonesia 2019, Hal.10

$25 \mathrm{lbid}$, Hal. 10

${ }^{26}$ Laporan Kinerja Badan Pembinaan Ideologi Pancasila Republik Indonesia 2019, Hal.11
}

kewargaan untuk mendorong kebijakan yang mengarah inklusi sosial ${ }^{27}$

Dalam upaya mewujudkan tujuan ini, BPIP memiliki sasaran strategis sebagai berikut :

a. Terjadinya revitalisasi dan reaktualisasi pemahaman nilai-nilai Pancasila

b. Terciptanya inklusi sosial di kalangan masyarakat

c. Terwujudnya keadilan sosial melalui pembangunan berbasis Pancasila

d. Terwujudnya pelembagaan pancasila pada setiap paraturan Perundangundangan

e. Teraktualisasinya nilai-nilai Pancasila melalui keteladanan Pancasila. ${ }^{28}$

Dalam mengimplementasikan sasaran strategis di atas, BPIP telah menjalankan dan melewati berbagai program untuk mengukur seberapa jauh strategi yang telah dirumuskan dapat tercapai dalam sistem ketatanegaraan Republik Indonesia. Berikut ini akan dipaparkan hasil kinerja dari BPIP, berdasarkan pada indikator sasaran strategis yang telah dirumuskan.

a. Terjadinya Revitalisasi dan Reaktualisasi Pemahaman Nilai-Nilai Pancasila

1. Mewarnai kebijakan dengan semangat Pancasila

Ideologi memiliki peranan penting dalam pembangunan suatu bangsa. Sebagai negara yang memiliki ideologi bangsa yakni Pancasila, dalam setiap kebijakan pembangunan yang ada di Indonesia haruslah berlandaskan Pancasila. Kepada para menteri dari Kabinet Indonesia Maju, Presiden Joko Widodo mengingatkan agar nilai-nilai Pancasila menjadi pertimbangan penting dalam kebijakan-kebijakan yang dikeluarkan Kementerian/Lembaga Negara.

Selain itu, Presiden
mengingatkan agar ideologi
Pancasila disebarkan melalui
beragam platform media sosial agar
semakin banyak lapisan masyarakat
yang terjangkau. Selain itu, saat ini
terdapat tantangan yang tak kalah
besar dan menantang dalam me

27 Ibid, Hal. 11

$28 \mathrm{lbid}$, Hal. 11 
nanamkan nilai-nilai Pancasila yakni bonus demografi Indonesia. Caracara lama tentunya tidak mampu menjangkau ketertarikan dan pemahaman generasi muda akan Pancasila sehingga diperlukan caracara yang di luar kebiasaan.

2. Arah kebijakan pembinaan ideologi Pancasila

\begin{tabular}{lcr}
\multicolumn{1}{c}{ Badan } & Pembinaan & Ideologi \\
Pancasila & (BPIP) & telah \\
menyelesaikan & rancangan & Garis
\end{tabular}
Besar Haluan Ideologi Pancasila (GBHIP). GBHIP merupakan rumusan Pedoman untuk seluruh elemen masyarakat Indonesia dalam kehidupan berbangsa dan bernegara. Selain itu, menjadi pedoman dalam menyusun, menjalankan, dan mengawasi kebijakan pembangunan nasional di segala bidang kehidupan sebagai implementasi dari pembumian nilainilai Pancasila oleh kementerian dan lembaga.

GBHIP menjadi rambu-rambu pembatas yang menuntun pemahaman tentang kedudukan Pancasila dalam kehidupan berbangsa dan bernegara, sekaligus bagaimana mewujudkan nilai-nilai Pancasila dalam pembangunan nasional. Penyelesaian konsep GBHIP dilakukan melalui serangkaian kegiatan, dari diskusi terpimpin hingga kegiatan akseptasi oleh para pakar dan akademisi.

3. Standarisasi dan Kurikulum Pendidikan dan Pelatihan Pembinaan Ideologi Pancasila

Sesuai tugas pokok dan fungsi yang termaktub dalam Peraturan Presiden Nomor 7 Tahun 2018 tentang BPIP, salah satu mandat BPIP adalah Penyusunan Standarisasi Pendidikan dan Pelatihan Pembinaan Ideologi Pancasila (SPPPIP) dan Kurikulum Pendidikan dan Pelatihan Pembinaan Ideologi Pancasila (KPPPIP). Proses penyusunan SPPPIP berkoordinasi dengan beberapa kementerian dan lembaga diantaranya
Kemenkominfo, Kemenag, LAN, LIPI, Kemenristekdikti dan Kemendikbud.

Untuk menghimpun ide, gagasan, dan masukan guna merumuskan sebuah produk kelembagaan naskah SPPPIP, BPIP dan stakeholders terus melakukan koordinasi dan diskusi yang terdiri dari beberapa seri diskusi kelompok terpimpin dan rapat koordinasi. Selain itu, BPIP juga melakukan koordinasi denga beberapa Kantor Kesatuan Bangsa dan Politik serta Pusat studi Pancasila di berbagai Universitas untuk melakukan Identifikasi kebutuhan/permasalahan kurikulum pendidikan dan pelatihan Pembinaan Ideologi Pancasila.

b. Terciptanya Inklusi Sosial di Kalangan Masyarakat

1. Internalisasi Falsafah Kehidupan Berbangsa dan Bernegara

Pancasila merupakan dasar, ideologi, pandangan dan falsafah hidup yang harus dipedomani bangsa Indonesia. Falsafah inilah yang menjadi pijakan dalam proses penyelenggaraan kehidupan bermasyarakat, berbangsa dan bernegara serta cita-cita proklamasi kemerdekaan diwujudkan. Sesuai dengan Keputusan Presiden Nomor 24 tahun 2016 tentang Hari Lahir Pancasila, tanggal 1 Juni 1945 ditetapkan sebagai Hari Lahir Pancasila. Pemerintah, sekaligus menetapkan hari libur pada hari lahir ideologi bangsa tersebutPancasila sebagai dasar dan ideologi Negara Republik Indonesia harus dibumikan agar menginternalisasi dalam kehidupan seluruh warga Negara Indonesia. Inilah yang menjadi semangat dari peringatan Hari Lahir Pancasila.

2. Refleksi kehidupan sosial politik Indonesia

Tahun 2019 banyak peristiwa besar yang terjadi dan mempengaruhi dinamika kehidupan sosial dan politik di Tanah Air. Begitupun dengan arus informasi yang masuk. Tak sedikit informasi yang masuk justru memberikan 
dampak negatif terhadap kehidupan sosial dan politik di Indonesia, sehingga apa yang menjadi nilai-nilai ideologi bangsa perlu semakin kuat untuk dibumikan.

Sebagai negara yang terus mengedepankan kemajuan, refleksi diperlukan untuk mendapatkan evaluasi dan masukan agar dapat lebih baik. Badan Pembinaan Ideologi Pancasila (BPIP) sebagai badan yang salah satu tugasnya melakukan pengendalian pembinaan ideologi Pancasila secara menyeluruh dan berkelanjutan, menjaring berbagai pendapat dan pandangan mengenai apa yang telah terjadi sepanjang satu tahun ke belakang dalam kehidupan sosial dan politik. Untuk bisa menjaga kehidupan sosial dan politik yang sesuai dengan Ideologi Pancasila maka BPIP harus menjadi lembaga terdepan dalam membumikan nilainilai Pancasila. Lembaga-lembaga lain nantinya akan mengikuti apa yang dirumuskan oleh BPIP.

3. Pembinaan Ideologi Pancasila untuk Aparatur Sispil Negara

Aparatur Sipil Negara (ASN) memiliki konsekuensi untuk memberikan keteladanan kepada masyarakat terkait dengan penerapan nilai-nilai Pancasila. Kesadaran ini penting untuk dijaga, mengingat ASN digaji oleh negara dan mendapat tugas untuk menjalankan tugas pokok serta fungsi pemerintahan. Untuk mewujudkan hal itu, Badan Pembinaan Ideologi Pancasila (BPIP) berusaha menyusun "Buku Utama Bahan Ajar Pembinaan Ideologi Pancasila (PIP) bagi Aparatur Negara".

Materi ajar ini tentu saja bukan sekadar dipahami, tapi juga harus menjadi acuan bagi ASN dalam mengaktualisasikan prinsip-prinsip Pancasila. Kementerian dan lembaga yang dilibatkan, antara lain: Kementerian Koordinator Bidang Pemberdayaan Manusia dan Kebudayaan, Kementerian
Pertahanan, Kementerian Dalam Negeri, Kementerian Pendayagunaan Aparatur Negara dan Reformasi Birokrasi, Kementerian Hukum dan HAM, Lembaga Administrasi Negara, Dewan Ketahanan Nasional, Lembaga Ketahanan Nasional, Badan Kepegawaian Nasional, dan Komisi Aparatur Sipil Negara.

4. Inklusi nilai dengan buku : Dialektika dan Masa Depan Bangsa

Buku Pancasila: Dialektika dan Masa Depan Bangsa untuk memperkuat dan memperdalam pengetahuan mengenai Pancasila yang dinilai mengalami kevakuman pasca Reformasi. Penyusunan buku ini dimulai sejak Maret dan sejak itu terus dilakukan pembahasan dan pengkajian dengan para pakar dan ahli guna mendapatkan hasil yang maksimal. Selain dengan para pakar, diskusi kelompok terpumpun juga digelar bersama Majelis Permusyawaratan Rakyat (MPR), serta melibatkan Kementerian Pendidikan dan Kebudayaan, Kementerian Riset Teknologi dan Pendidikan Tinggi dan Dikti, dan Kementerian Agama. Untuk mendapatkan konten yang kontekstual, penyusunan buku juga melibatkan para pemuka agama dan generasi milenial. Buku ini dimaksudkan untuk menjadi bahan bacaan utama para pendidikan di berbagai lembaga pendidikan, universitas, dan kalangan Aparatur Sipil Negara (ASN).

5. Konsensus bersama BUMN : bersama menjaga keutuhan

Pancasila

Badan Pembinaan Ideologi Pancasila (BPIP) melaksanakan Musyawarah Nasional Pemantapan Pembinaan Ideologi Pancasila dengan Badan Usaha Milik Negara (BUMN). Tujuannya adalah mengajak elemen masyarakat termasuk BUMN untuk memiliki komitmen bersama dalam menjaga consensus empat pilar: UUD 1945, NKRI, Bhinneka Tunggal, dan Pancasila. Terdapat 47 BUMN 
mendukung komitmen ini. BPIP berpandangan bahwa seluruh elemen bangsa wajib membangkitkan kesadaran masyarakat akan pentingnya ideologi berbangsa dan bernegara demi menegakkan cita-cita kemerdekaan.

Apalagi saat ini, habituasi dan penanaman nilai Pancasila mengalami tantangan serius, antara lain oleh distraksi perkembangan informasi teknologi dan digital. Pengaktualisasian nilai-nilai Pancasila sekarang terganggu oleh berita palsu, penolakan agama, penolakan ideologi, dan guncangan perubahan yang begitu besar di dunia digital dan informasi. Karena itu penting bagi seluruh elemen masyarakat bergandengan tangan untuk bersama menjaga dan mengamalkan nilai-nilai Pancasila dalam kehidupan berbangsa dan bernegara.

6. Penanaman nilai-nilai Pancasila bagi pelajar Indonesia

Nilai-nilai Pancasila kerap dikeluhkan kurang membumi di kalangan milenial. Dalam upaya menyasar generasi muda adalah dengan kegiatan di luar ruangan, bukan di dalam kelas yang kadang menjemukan. Badan Pembinaan Ideologi Pancasila menginisiasi penanaman nilai-nilai Pancasila melalui Kemah Pancasila Pelajar Indonesia.

Kemah diikuti oleh pelajar Sekolah Menengah Atas (SMA) dan Sekolah Menengah Kejuruan (SMK) dari 30 kota se- Indonesia, seperti: Lampung, Gorontalo, Jakarta, Banten, Bekasi, Cirebon, Tegal, Brebes, dan Pekalongan. Terdapat pula pelajar asal Kendal, Batang, Banyumas, Tasikmalaya, Cilacap, Purbalingga, Blora, Temanggung, Purworejo, Magelang, Klaten, Sragen, serta Boyolali. Selain itu terdapat pula pelajar dari Jawa Timur seperti Ngawi, Wonogiri, Jember, Surabaya, Situbondo, Malang, Lumajang dan Pasuruan.

Kalangan pelajar perlu terus bersikap kritis terhadap dinamika sosial masyarakat. Banyaknya postingan hoax dan ujaran kebencian, terutama pada sosial media serta fenomena kekerasan, yang kerap melibatkan kalangan pelajar. Persoalan tersebut perlu disikapi dengan bijak. Pengamalan nilai-nilai Pancasila di kalangan pelajar harus menjadi laku hidup dalam bermasyarakat.

c. Terwujudnya Keadilan Sosial Melalui Pembangunan Berbasis Pancasila

1. Penguatan kaum rentan untuk pembangunan berkeadilan sosial melalui Syiar Pancasila bagi Perempuan Indonesia

Upaya mewujudkan pesan moral pelaksanaan nilai-nilai Pancasila dalam kehidupan berbangsa dan bernegara, melalui momentum Hari Ibu sebagai syiar nilai-nilai Pancasila kepada para perempuan Indonesia untuk terlibat menjadi bagian penting dalam membangun bangsa. Sebab konstitusi tidak pernah membedakan antara kali-laki dan perempuan. Semuanya memiliki hak dan kesempatan yang sama.

Ketua Dewan Pengarah dalam sambutannya mengingatkan bahwa Indonesia pernah mencatat seorang perempuan menjadi Presiden RI ke lima. Karena itu, dia mengajak para perempuan untuk berjuang, termasuk di bidang politik, tanpa merasa ada hambatan.

2. Nilai Pancasila Menuju Negara yang Damai dan Toleran untuk Indonesia yang Lebih Maju

Sejalan dengan semangat hari Hak Asasi Manusia Sedunia, Indonesia lebih dahulu memiliki nilai yang tertuang dalam Pancasila. Sila Kelima untuk Pancasila, menyebutkan Keadilan Sosial Bagi Seluruh Rakyat Indonesia. Hal ini menegaskan bahwa setiap orang di Indonesia memiliki kesempatan dan perlakuan yang sama di dalam seluruh aspek kehidupan, dari bidang ekonomi, hukum, politik, sosial, hingga agama. Untuk bisa hidup dalam HAM yang terjamin, selain peraturan yang mendukung, 
juga diperlukan kerja sama dari seluruh lapisan masyarakat dan pemangku kepentingan lainnya. Masyarakat Indonesia harus mampu menciptakan kehidupan yang damai dan toleran agar Indonesia dapat lebih maju.

Oleh karena itu, agar dapat mewujudkan negara yang damai dan toleran, penguatan Ideologi Pancasila menjadi penting, sehingga ideologi-ideologi yang bertentangan dan menciptakan sikap intoleran dapat dicegah. Selain itu, toleransi tidak hanya sebatas agama akan tetapi juga diperlukan toleransi ekonomi sehingga taraf kehidupan masyarakat Indonesia bisa meningkat.

3. Kelompok Rentan Pengaruh Negatif : Generasi Milenial Lawan Konten Negatif

Badan Pembinaan Ideologi Pancasila (BPIP) menggelar Pembinaan Ideologi Pancasila bagi Pendongeng, Youtuber, dan Influencer dengan tujuan konten Pancasila dikemas dengan menarik, karakter, dan laku hidup Pancasila dapat dicontoh oleh masyarakat luas. Melalui media sosial, daya jangkau informasi nilai-nilai Pancasila akan semakin luas.

Generasi milenial harus bisa mengarusutamakan Pancasila dalam pembangunan berkeadilan sosial dengan gayanya sendiri sesuai dengan kemajuan teknologi saat ini. Dengan demikian, konten negatif yang berpotensi merusak moral dan keutuhan bangsa di media sosial dapat dilawan dengan konten positif dan inspiratif. Youtuber dan influencer saat ini mempunyai nilai lebih untuk menyampaikan pesan kepada masyarakat. Mereka memiliki banyak pengikut di media sosial, sehingga ajak kebaikan, terutama implementasi nilai-nilai Pancasila dalam kehidupan, akan banyak menyentuh masyarakat.

d. Terwujudnya Pelembagaan Pancasila Pada Setiap Paraturan PerundangUndangan
Salah satu tugas penting Badan Pembinaan Ideologi Pancasila (BPIP) adalah mewujudkan sinkronisasi antara peraturan perundangundangan dengan nilai-nilai Pancasila. Dalam konteks itulah, BPIP melakukan evaluasi, baik terhadap undang-undang, peraturan kementerian/lembaga, maupun peraturan daerah.

Dari hasil identifikasi, sepanjang tahun 2019, terdapat 84 undangundang, dan 42 peraturan daerah yang dianalisis. Sejalan dengan peran evaluasi pembinaan ideologi Pancasila, BPIP juga melakukan sosialisasi dan advokasi. Hingga akhir 2019, BPIP telah melakukan finalisasi penetapan indikator nilainilai Pancasila dalam pembentukan perundang-undangan di Indonesia serta evaluasinya. Tujuan utama advokasi yang dilakukan kepada para pemangku kepentingan, antara lain adalah agar regulasi yang dikeluarkan menginternalisasikan nilai-nilai Pancasila.

e. Teraktualisasinya Nilai-Nilai Pancasila Melalui Keteladanan Pancasila

Badan Pembinaan Ideologi dan Pancasila (BPIP) dalam upaya mewujudkan sasaran teraktualisasinya nilai-nilai Pancasila melalui keteladanan Pancasila, memberikan apresiasi kepada 74 tokoh yang menjadi ikon Pancasila. Apresiasi bertajuk 'Pemberian Apresiasi 74 Ikon Prestasi Pancasila' merupakan rangkaian perayaan HUT ke-74 Kemerdekaan Indonesia. Jumlahnya sesuai dengan usia Kemerdekaan RI.

Pemberian Apresiasi diberikan BPIP kepada para tokoh inspiratif yang dianggap mampu menggerakkan masyarakat untuk mengamalkan Pancasila. Pemberian penghargaan itu didasarkan pada 4 kriteria yaitu sains dan inovasi, olahraga, seni budaya dan bidang kreatif, serta social entrepreneur. Mereka yang mendapat apresiasi 
sangat beragam yakni berusia 11 tahun hingga 96 tahun $^{29}$.

\section{KESIMPULAN}

Berdasarkan pada hasil penelitian dan pembahasan dapat ditarik kesimpulan dari Eksistensi Badan Pembinaan Ideologi Pancasila (BPIP) dalam sistem ketatanegaraan Republik Indonesia merupakan badan pembantu presiden setingkat kementerian yang bertanggung jawab pula kepada presiden. Tugas, Fungsi dan wewenangnya ini diatur dalam Perpres Nomor 7 Tahun 2018 dan Hak keuangan dan fasilitas lainnya pada Perpres Nomor 42 Tahun 2018. BPIP sebagai badan/kelembagaan yang berperan besar bagi pembinaan ideologi Pancasila dalam sistem ketatanegaraan Indonesia sesuai dengan yang diamanatkan oleh UUD 1945, yang sekaligus memantapkan peran Presiden sebagai pemegang kekuasaan pemerintahan dalam upaya menanamkan, menjaga dan memelihara ideologi Pancasila sebagai ideologi Negara. Karena, selain menjalankan amanat UUD 1945, BPIP merupakan badan yang turut mendukung program pemerintahan, yaitu program Nawacita.

Implementasi kewenangan Badan Pembinaan Ideologi Pancasila (BPIP) sudah berlangsung semenjak BPIP terbentuk semenjak awal tahun 2018. Dalam mengimplementasikan tugas dan fungsinya BPIP memiliki 5 sasaran strategis berdasarkan Peraturan BPIP nomor 5 Tahun 2018, yaitu : a) Terjadinya revitalisasi dan reaktualisasi pemahaman nilai-nilai Pancasila; b) Terciptanya inklusi sosial di kalangan masyarakat; c) Terwujudnya keadilan sosial melalui pembangunan berbasis Pancasila; d) Terwujudnya pelembagaan pancasila pada setiap paraturan Perundang-undangan; d) Teraktualisasinya nilai-nilai Pancasila melalui keteladanan Pancasila.

Sehingga saran peneliti adalah pertama, Pemerintah daerah beserta stakeholdemya harus secara massive membuat program atau kegiatan-kegiatan yang mendorong percepatan pembinaan ideologi Pancasila ini sampai pada tingkat desa. Karena, pembinaan ideologi Pancasila ini harus seiring sejalan dengan percepatan pembangunan

${ }^{29}$ Ibid, Hal. 35 ekonomi yang sudah mulai digalakkan dan menjadi prioritas pemerintah pusat. Kedua, kampus-kampus dan lembaga-lembaga pendidikan lainnya harus terus berkoordinasi dan mensinkronkan kerja pembinaan ideologi Pancasila ini dengan berbagai pihak, terutama dengan pemerintah daerah guna mempercepat dan menguatkan upaya penanaman, penjagaan dan pemeliharaan ideologi Pancasila sebagai ideologi Negara.

\section{DAFTAR PUSTAKA}

Jimly Asshiddiqie, Hukum Tata Negara dan Pilar-Pilar Demokrasi, Jakarta, Konpress, 2005.

2006, Perkembangan dan Konsolidasi Lembaga Negara Pasca Reformasi, Sekretaris Jenderal dan Kepaniteraan Mahkamah Konstitusi RI, Jakarta.

Lintje Anna Marpaung, Hukum Tata Negara Indonesia, CV. Andi Offset, Yogyakarta, 2018.

Laporan Kinerja Badan Pembinaan Ideologi Pancasila Republik Indonesia 2019.

Mahkamah Konstitusi, Undang-Undang Dasar Negara Republik Indonesia Tahun 1945, Kepaniteraan dan Sekretariat Jenderal Mahkamah Konstitusi, Cetakan Ketujuh, Januari 2017.

Munir Fuady, Teori Negara Hukum Modern (Rechtstaat), PT. Refika Aditama, Bandung, 2009.

Pimpinan MPR dan Badan Sosialisasi MPR RI Periode 2014 2019, Materi Sosialisasi Empat Pilar MPR RI, Cet. $\mathrm{Ke}-7$, Sekretariat Jenderal MPR RI, 2017.

Sirajuddin, Winardi, Dasar-Dasar Hukum Tata Negara Indonesia, Setara Press (Kelompok Intrans Publishing), Malang, 2016 
Sudikmo Mertokusomo, Penemuan Hukum, Liberty, Yogyakarta, 2004.

Media, Kompas Cyber, Nawa Cita", 9 Agenda Prioritas Jokowi-JK-Kompas.com. (9-5-2020)

Rudy Poycarpus, UKP PIP Bakal Setingkat Kementerian, http://mediaindonesia. com/read/detail/136983-ukp-pipbakalsetingkat-kementerian, (103-2020)

Republik Indonesisa, Peraturan Presiden Nomor 54 Tahun 2017 Tentang Unit Kerja Presiden Pembinaan Ideologi Pancasila

Republik Indonesisa, Peraturan Presiden Nomor 7 Tahun 2018 tentang Badan

Pembinaan Ideologi Pancasila 